\title{
Afghan Chehelghoza (Pinus gerardiana L.) Pine Nut Diet Enhances the Learning and Memory in Male Rats
}

\author{
Kawsar Alami iD ' \\ Sayed Yousof Mousavi (D) ${ }^{2}$ \\ 'Research and Technology Center, \\ Khatam Al-Nabieen University, Kabul, \\ Afghanistan; '2Department of Physiology, \\ Medical Faculty, Khatam Al-Nabieen \\ University, Kabul, Afghanistan
}

\section{Video abstract}

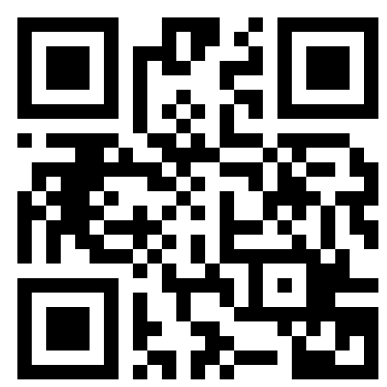

Point your SmartPhone at the code above. If you have a QR code reader the video abstract will appear. Or use: https://youtu.be/nEMcA5chp_U
Correspondence: Sayed Yousof Mousavi Department of Physiology, Medical Faculty, Khatam Al-Nabieen University, Ith Street of Karte 4, Kabul, Afghanistan Tel +93796850084

Email Mousavi.knurtc@knu.edu.af
This article was published in the following Dove Press journal: Nutrition and Dietary Supplements

Purpose: The aim of this study is the evaluation of the effect of Afghan Chehelghoza as a constituent of diet on behavioral parameters, especially learning and memory of male rats. Methods: Rats were divided into six groups: control group, diazepam group as the positive control, and 2, 6, 12 and 25\% chehelghoza-treated groups, which received chehelghoza combined with their food for 28 days. After treatment, the rat's behavior was evaluated by Y-maze, elevated plus maze, Morris water maze and radial arm maze. In addition, their brain was extracted and weighed. The body weight of rats was also measured during the study.

Results: The results showed that the time spent in target quadrant and brain weight were increased in 12 and $25 \%$ chehelghoza-treated groups significantly $(\mathrm{P}<0.05)$. Also, the difference between the percentage of spontaneous alternation and the number of crossing, percentage of time spent in and the number of entries into open arms of only $25 \%$ chehelghoza-treated and the control groups was significant. Besides, on day 28 , the body weight of all chehelghoza-treated groups was diminished as compared with the control group.

Conclusion: We can conclude that chehelghoza combination with food in high doses can improve the spatial working memory and reference memory, increase the brain weight, as well as reduction in anxiety behavior.

Keywords: anxiety, learning, memory, Chehelghoza, rat

\section{Introduction}

Human and thus brain physiology like any other organs need nutrients. The brain uses these nutrients for development and maintenance of its structure, thereby functions in an appropriate and coordinate manner. ${ }^{1}$ Research in last decades provides evidence of the effect of nutritional factors on specific molecular systems and mechanisms involved in mental function. Different constituents of diet and nutrients are effective on human cognition, so signals mediated by nutrients affect on the metabolism of energy, membrane fluidity, regulation of neurotransmitter pathways, signal transduction, synaptic transmission, synaptic plasticity and other brain processes. ${ }^{2}$ Synaptic plasticity is considered as the cellular basis for learning and memory, which results from the interaction between organism and environment. ${ }^{3,4}$ The learning and memory capability is also highly related to increase in brain weight or size, due to increase in cell size and the number of dendrites. ${ }^{5}$ Search about factors that can increase the number of synapses and synaptic plasticity may develop new strategies for improvement of learning and memory functions. ${ }^{6}$ 
Nature gifts various plants, fruits and nuts to human. ${ }^{7}$ Chehelghoza pine nut belongs to Pinaceae family. It is one of 25 pine nut types, which produces edible nuts and uses all over the world. ${ }^{8}$ Chehelghoza was found in 2000-3350 meter heights, ${ }^{8-10}$ in India, Pakistan, China and Afghanistan. ${ }^{8-12}$ In Afghanistan, chehelghoza trees are found especially in Paktia, Paktika, Laghman and Khost Provinces. ${ }^{13}$ People consume this kind of pine nut in both raw and roasted forms. It is used in combination with different loaves of bread, candies, desserts, cakes, and also in meat or vegetable foods. ${ }^{8,14}$ Chehelghoza is known as an important and tasty dry fruit. ${ }^{9}$

Generally, pine nuts are considered as a reservoir of different nutrients including proteins, carbohydrates, fibers, minerals, and especially oil substances. ${ }^{8}$ Chehelghoza pine nuts are a good reservoir of energy $(628 \mathrm{kcal})^{12}$ and contain unsaturated fatty acids, carbohydrates, ${ }^{8}$ proteins, ${ }^{11}$ minerals, vitamins, ${ }^{12}$ antioxidants, ${ }^{15}$ and phytosterols. ${ }^{14}$ About $49.9 \%$ of chehelghoza is fat, mostly unsaturated fatty acids. Fatty acids that present in chehelghoza oil are stearic acid (0.3\%), linoleic acid (51.3\%), linolenic acid (1.5\%), oleic acid (39.7), arachidic acid (2.1\%) and palmitic acid (7.2\%). ${ }^{8,9}$ Chehelghoza also contains a large amount of plant protein. It is considered as a source of essential amino acids, especially arginine. ${ }^{11}$

Chehelghoza pine nuts have potent biological activity. ${ }^{8}$ They have carminative, stimulant, expectorant, ${ }^{9,10}$ lowering blood cholesterol, ${ }^{12}$ and anti-diabetic properties. ${ }^{16}$

Despite these beneficial constituents and properties of chehelghoza and significant effect of diet on brain processes, there is not any evidence of study on the effect of dietary chehelghoza on learning and memory. Hence, this is the first study, which initiated to investigate the effect of chehelghoza as a constituent of diet on behavioral parameters, especially learning and memory of rats.

\section{Materials and Methods \\ Materials}

The main materials and equipment used in this study were chehelghoza (Afghanistan), diazepam (Caspian Tamin, Iran), Y-maze, elevated plus maze (EPM), Morris water maze (MWM), and radial arm maze (RAM), which are constructed in research and technology center of Khatam Al-Nabieen university (KNURTC).

\section{Chehelghoza and Diet}

Raw seeds of chehelghoza pine nut from Alisheng, Laghman province of Afghanistan were purchased from the local market. The nuts were identified in Kabul university, Faculty of science, by Prof. Nasim Sediqi, Department of Pharmacognosy, Faculty of pharmacy, Kabul university, with herbarium code of KUFS017783. The nuts are pilled manually, ground and mixed with standard rodent food (Javaneh Khorasan, Iran).

\section{Animals}

Thirty-six adult Sprague Dawley male rats, with body weight between 180 and $220 \mathrm{~g}$, were randomly selected from KNURTC. Rats had at least 7 days' acclimatization period before starting of the actual experiments. Rats were housed in Plexy-glass cages, controlled-temperature $\left(23 \pm 2^{\circ} \mathrm{C}\right)$ room and a 12-hour light/dark cycle (lights on at 7 a.m.). The ethic research board of Khatam Al-Nabieen University approved the experimental protocol (Approval No. AF. KNU.REB.1397.16) on 2018 and the study was conducted following the ethical guidelines set by the eighth edition of the National Institute of Health (NIH) guide for the care and use of laboratory animals. Rats were free in access to food and water, and were carefully handled to reduce the housing and experiment period unwanted stress to minimum. The body weight and food consumption of all rats were monitored throughout of study.

Rats divided into six groups $(\mathrm{n}=6)$ as following:

Group 1 (Control group): Rats of this group received standard rodent food without chehelghoza for 28 days.

Group 2 (2\% group): Rats of this group received 2\% chehelghoza combined with standard rodent food for 28 days.

Group 3 (6\% group): Rats of this group received 6\% chehelghoza combined with standard rodent food for 28 days.

Group 4 (12\% group): Rats of this group received 12\% chehelghoza combined with standard rodent food for 28 days.

Group 5 (25\% group): Rats of this group received 25\% chehelghoza combined with standard rodent food for 28 days.

Group 6 (Diazepam group): Rats of this group received standard rodent food without chehelghoza for 28 days. They considered as a positive control group for the EPM test and received $1.5 \mathrm{mg} / \mathrm{kg}$ diazepam as a standard antianxiety drug, 1 hour before the EPM test. ${ }^{17}$ 
The oral pretreatment design of the study was the same as described earlier. ${ }^{18}$

\section{Behavioral Tests Y-Maze}

A black plexy-glass Y-maze $(50 \times 30 \times 11)$ used in this study to evaluate the spatial working memory. Rats were placed in the Y-maze to explore for $8 \mathrm{~min}$ without any reward (eg food and water). The number of arm entries was counted and considered as an index of locomotor activity. Successive entries into three different arms are considered as a spontaneous alternation (\%SA). ${ }^{17}$ The maze was thoroughly cleaned with damp cotton after each rat's experiment to remove any smell cues.

\section{EPM}

The behavior of rats was assessed in EPM for evaluation of exploring, anxiety and locomotor activity. ${ }^{17}$ The basis of the EPM test is the principle that maze exposure causes an approaching conflict which is significantly greater than that caused by exposure to the closed arms. ${ }^{19,20}$ A wooden EPM consists of a central area $(10 \times 10 \mathrm{~cm}$ wide $)$, two closed arms $(50 \times 10 \times 40 \mathrm{~cm}$ wide), and two open arms $(50 \times 10 \mathrm{~cm}$ wide) placed $50 \mathrm{~cm}$ above the ground. The rats were placed in the central area of EPM, facing one closed arm, to exploring the maze for 5 minutes. The number of entries into and time spent in open and closed arms was evaluated and the percentage of time spent in open arms was calculated. The number of entries into open and closed arms (number of the crossing) considered as a behavior of exploration. ${ }^{17,19,20}$ The maze was cleaned with damp cotton after each rat's experiment to remove any smell cues.

\section{MWM}

MWM was performed as a gold standard test for assessing spatial learning and memory. ${ }^{21}$ A circular black stainless steel tank (diameter of $180 \mathrm{~cm}$; height of $60 \mathrm{~cm}$ ), filled with water $\left(22 \pm 1{ }^{\circ} \mathrm{C}\right)$. The distance between circular platform and the surface of water was $1 \mathrm{~cm}$. The colour of water became opaque by adding non-fat dry milk to make the platform invisible. Some spatial cues were placed outside of the tank in the same position throughout of experiment to facilitate spatial memory. The position of experimenter also remained consistent throughout of experiment. The tank was divided into four quadrants as northeast, northwest, southeast, southwest and platform placed in the northeast quadrant. Rats trained for 4 days with two blocks. Each block consists of four trials with a rest of 5 minutes between two blocks. During training, each rat allowed swimming until 90 $\mathrm{s}$ to locating the platform and spent $30 \mathrm{~s}$ period between two trials. A video camera fixed above the tank and the time taking to locate the platform (escape latency) was recorded. On day 5, after removal of the platform, rats were allowed to swim for $60 \mathrm{~s}$ (probe trial), and the percentage of time spent in the target quadrant was recorded. ${ }^{22}$ After each experiment, the rats were dried with a clean cloth and placed in a clean cage.

\section{RAM}

RAM was used to evaluate the working and reference spatial memory. RAM is a reward-motivated model of spatial memory. ${ }^{23,24}$ The maze consists of a central platform (32 $\mathrm{cm}$ wide), and eight-arm $(58 \times 12 \times 38 \mathrm{~cm})$, elevated $58 \mathrm{~cm}$ above the floor, with various visual cues in the surroundings. A circular food cup with $45 \mathrm{mg}$ food pellet placed at the end of each arm as bait. The food of animals was restricted for 1 week before the RAM experiment to reach the body weight into $85 \%$ of their initial weight. Rats were trained for 10 minutes in 3 days, where all arms were opened and baited. On day 4, the performance tests, which consist of two phases (training and test) were conducted. In the training phase, the four arms were randomly blocked and the remaining arms were baited. The rats were allowed $5 \mathrm{~min}$ to retrieve the baits. After a 5-min delay, all arms were open, but the bait was only in the previously blocked arms. In this phase, rats were allowed to retrieve the baits for $5 \mathrm{~min}$, the working memory errors (MWE, re-entries into baited and without bait arms) and reference memory errors (RME, entering without bait arms) were recorded. ${ }^{24,25}$ The maze was thoroughly cleaned with damp cotton after each rat's experiment to remove any smell cues.

\section{Brain Extraction and Weighing}

One day after the last behavioral test, rats were decapitated, brain extracted and placed in an ice-filled petri dish to clean. The cerebellum was rapidly removed and the remaining brain weighed (wet brain weight). ${ }^{26,27}$

\section{Statistical Analysis}

Graph pad prism (6.07) software was used for statistical analysis. Parameters without considering the time were analyzed by One-way ANOVA test or Kruskal Wallis test and the parameters with consideration of time were analyzed by Two-way ANOVA $(\mathrm{P}<0.05)$. 


\section{Results}

\section{Effect of Chehelghoza on \%SA and Number of Arm Entries}

The $\%$ SA was considerably increased in $25 \%$ group $(78.07$ $\pm 3.62)$, but not in $2 \%(76.20 \pm 3.99), 6 \%(71.12 \pm 4.13)$ and $12 \%(68.59 \pm 3.27)$ groups as compared with the control group (64.30 \pm 3.27$)(\mathrm{P}<0.05)$ (Figure 1 and Table 1). Also, the difference in the number of arm entries between $2 \%$ (21.33 \pm 2.09$), 6 \%(22.33 \pm 2.04), 12 \% \quad(27.67 \pm 2.44)$ and $25 \%(25.50 \pm 2.14)$ groups and the control group (28.17 \pm 1.99 ) was not significant (Figure 2 and Table 1 ).

\section{Effect of Chehelghoza on the Percentage} of Time Spent in and Number of Entries into Open Arms and Number of Crossing The percentage of time spent in open arms was increased in diazepam $(18.79 \pm 2.20)$ and $25 \%(15.22 \pm 2.91)$ groups significantly, in comparison with the control group (3.94 \pm 1.92 ). However, there was not a significant difference between $2 \%(4.41 \pm 1.90), 6 \%(4.96 \pm 2.06)$ and $12 \%$ (4.59 $\pm 2.65)$ groups and the control group $(3.94 \pm 1.92)$ (Figure 3 and Table 2). The number of entries into open arms in diazepam (4.00 \pm 0.52$)$ and $25 \%$ (3.67 \pm 0.33$)$ groups was significantly increased, as compared with the control group $(0.67 \pm 0.33)$. However, there was not a significant difference between $2 \%(1.50 \pm 0.56), 6 \%(1.33 \pm 0.42)$ and $12 \%$ $(1.17 \pm 0.65)$ groups and the control group $(0.67 \pm 0.33)$ (Figure 4 and Table 2). The number of crossing was significantly increased in diazepam (13.67 \pm 2.43$)$ and

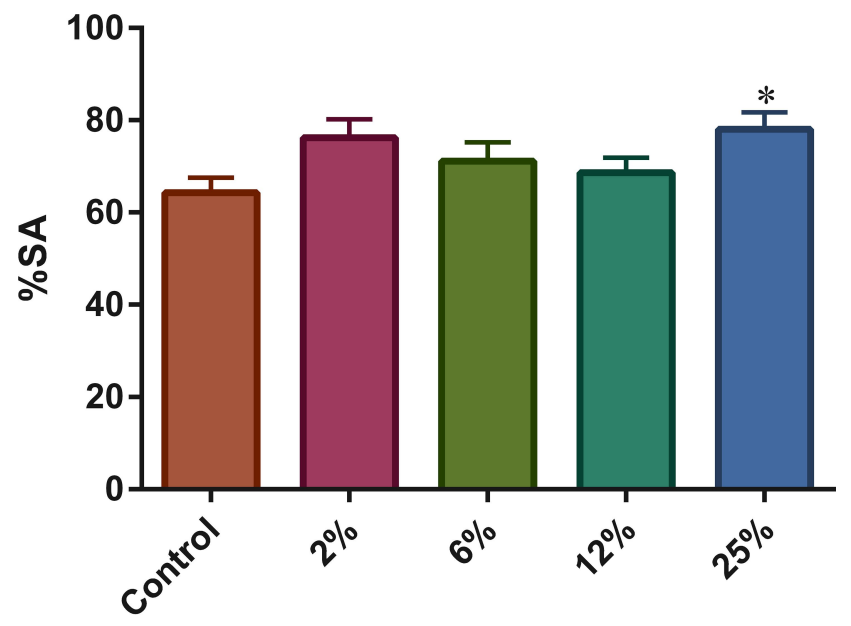

Figure I Effect of chehelghoza on \%SA.

Notes: Data are shown as mean \pm SEM. $* \mathrm{P}<0.05$ as compared with the control group.

Abbreviation: \%SA, percentage of spontaneous alternation.
Table I Effect of Chehelghoza on \%SA and the Number of Arm Entries

\begin{tabular}{|l|l|l|}
\hline \multirow{2}{*}{ Groups } & \multicolumn{2}{|l|}{ Parameters } \\
\cline { 2 - 3 } & \%SA & Number of Arm Entries \\
\hline Control & $64.30 \pm 3.27$ & $28.17 \pm 1.99$ \\
$2 \%$ & $76.20 \pm 3.99$ & $21.33 \pm 2.09$ \\
$6 \%$ & $71.12 \pm 4.13$ & $22.33 \pm 2.04$ \\
$12 \%$ & $68.59 \pm 3.27$ & $27.67 \pm 2.44$ \\
$25 \%$ & $78.07 \pm 3.62 *$ & $25.50 \pm 2.14$ \\
\hline One-way ANOVA & $F=2.326$ & $F=2.055$ \\
& $d f=4$ & $d f=4$ \\
& $P=0.084$ & $P=0.117$ \\
\hline
\end{tabular}

Notes: Data are shown as mean \pm SEM. ${ }^{*} \mathrm{P}<0.05$ as compared with the control group. Abbreviations: $d f$, degrees of freedom; \%SA, percentage of spontaneous alternation.

$25 \%(11.50 \pm 1.02)$ groups, as compared with the control group (4.83 \pm 1.35$)$. However, there was not a significant difference between $2 \%(7.33 \pm 1.73), 6 \%(8.50 \pm 1.93)$ and $12 \%(10.50 \pm 1.73)$ groups and the control group (4.83 \pm 1.35 ) (Figure 5 and Table 2).

\section{Effect of Chehelghoza on Escape Latency} and Time Spent in the Target Quadrant

The difference between the escape latency of control and each chehelghoza-treated groups in either 1-4 days was not significant (Figure 6 and Table 3). Also, the time spent in the target quadrant was considerably increased by $12 \%$ (26.01 \pm 3.94$)$ and $25 \%(26.85 \pm 4.55)$ groups, in comparison with the control group $(11.21 \pm 2.47)(\mathrm{P}<0.05)$. However, the difference between the control $(11.21 \pm 2.47)$ and each

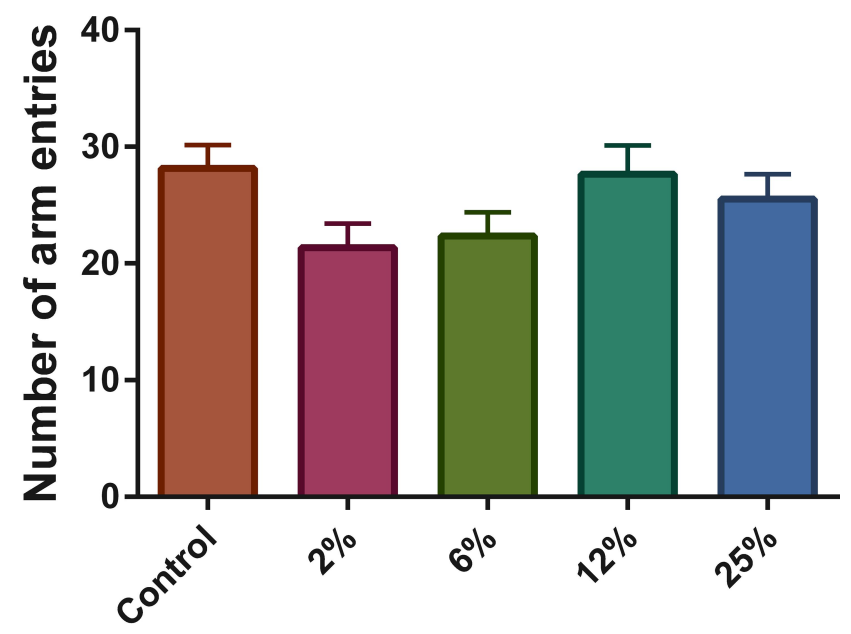

Figure 2 Effect of chehelghoza on the number of arm entries. Notes: Data are shown as mean \pm SEM. 


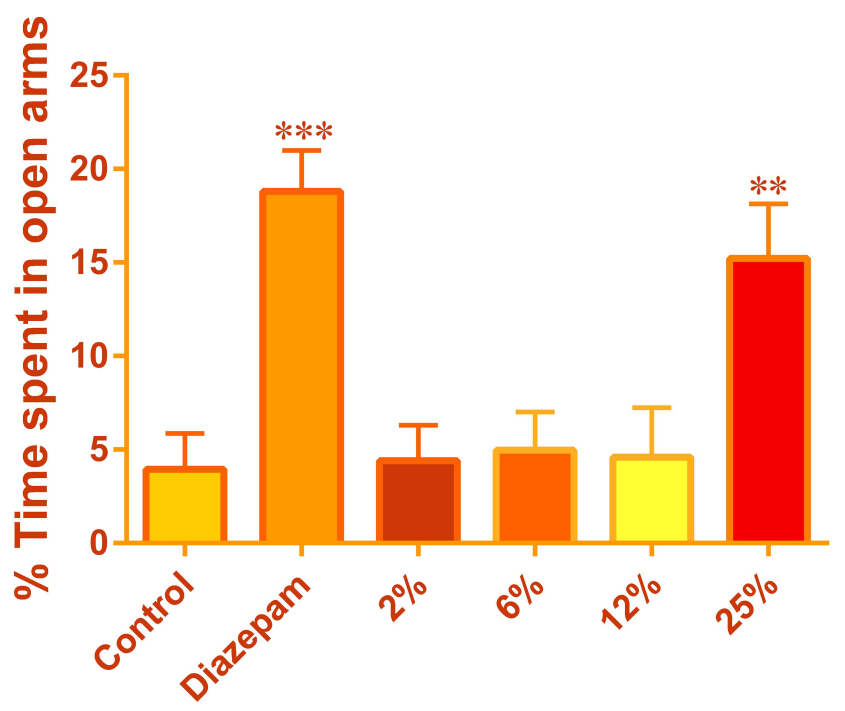

Figure 3 Effect of chehelghoza on the percentage of time spent in open arms. Notes: Data are shown as mean \pm SEM. $* * \mathrm{P}<0.01$, $* * * \mathrm{P}<0.001$ as compared with the control group.

$2 \%(23.79 \pm 2.72)$ and $6 \%(20.70 \pm 4.46)$ groups was not significant (Figure 7 and Table 3 ).

\section{Effect of Chehelghoza on WME and RME}

There was not a significant difference between WME of control $(6.83 \pm 0.87)$ and each $2 \%(3.83 \pm 0.48), 6 \%(8.67$ $\pm 1.89), 12 \%(5.17 \pm 0.91)$ and $25 \%(8.17 \pm 0.87)$ groups (Figure 8 and Table 4). There was also not a significant difference between RME of control (5.50 \pm 0.43$)$ and each $2 \%$ (4.67 \pm 0.49$), 6 \%(6.50 \pm 1.28), 12 \%(4.67 \pm 0.67)$ and $25 \%(6.17 \pm 0.83)$ groups (Figure 9 and Table 4$)$.

Table 2 Effect of Chehelghoza on the Percentage of Time Spent in Open Arms, Open Arm Entries and a Number of Crossings

\begin{tabular}{|l|l|l|l|}
\hline \multirow{2}{*}{ Groups } & \multicolumn{3}{|l|}{ Parameters } \\
\cline { 2 - 4 } & $\begin{array}{l}\text { \% Time Spent in } \\
\text { Open Arms }\end{array}$ & $\begin{array}{l}\text { Number of } \\
\text { Entries into } \\
\text { Open Arms }\end{array}$ & $\begin{array}{l}\text { Number of } \\
\text { Crossing }\end{array}$ \\
\hline Control & $3.94 \pm 1.92$ & $0.67 \pm 0.33$ & $4.83 \pm 1.35$ \\
$2 \%$ & $4.41 \pm 1.90$ & $1.50 \pm 0.56$ & $7.33 \pm 1.73$ \\
$6 \%$ & $4.96 \pm 2.06$ & $1.33 \pm 0.42$ & $8.50 \pm 1.93$ \\
$12 \%$ & $4.59 \pm 2.65$ & $1.17 \pm 0.65$ & $10.50 \pm 1.73$ \\
$25 \%$ & $15.22 \pm 2.91 * *$ & $3.67 \pm 0.33^{* * *}$ & $11.50 \pm 1.02^{*}$ \\
Diazepam & $18.79 \pm 2.20^{* * *}$ & $4.00 \pm 0.52^{* * *}$ & $13.67 \pm 2.43^{* *}$ \\
\hline $\begin{array}{l}\text { One-way } \\
\text { ANOVA }\end{array}$ & $\mathrm{F}=8.14$ & $\mathrm{f}=8.44$ & $\mathrm{~F}=3.23$ \\
& $\mathrm{P}<0.000 \mathrm{I}$ & $\mathrm{df}=5$ & $\mathrm{P}=5$ \\
\hline
\end{tabular}

Notes: Data are shown as mean \pm SEM. $* \mathrm{P}<0.05$, $* * \mathrm{P}<0.01$, $* * * \mathrm{P}<0.00 \mathrm{I}$ as compared with control group.

Abbreviation: $d f$, degrees of freedom.

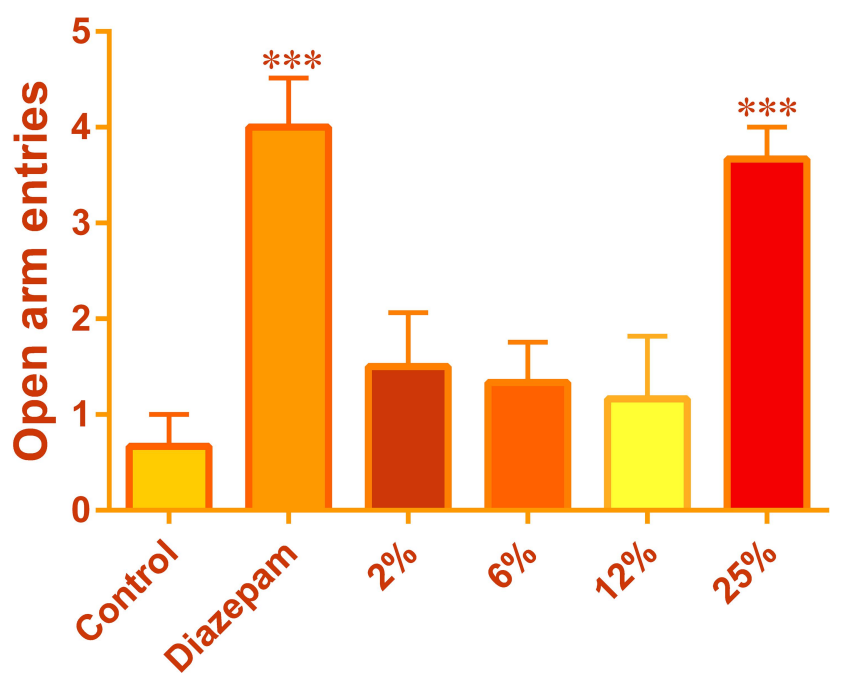

Figure 4 Effect of chehelghoza on the open arm entries.

Notes: Data are shown as mean $\pm \mathrm{SEM}$. $* * * \mathrm{P}<0.001$ as compared with the control group.

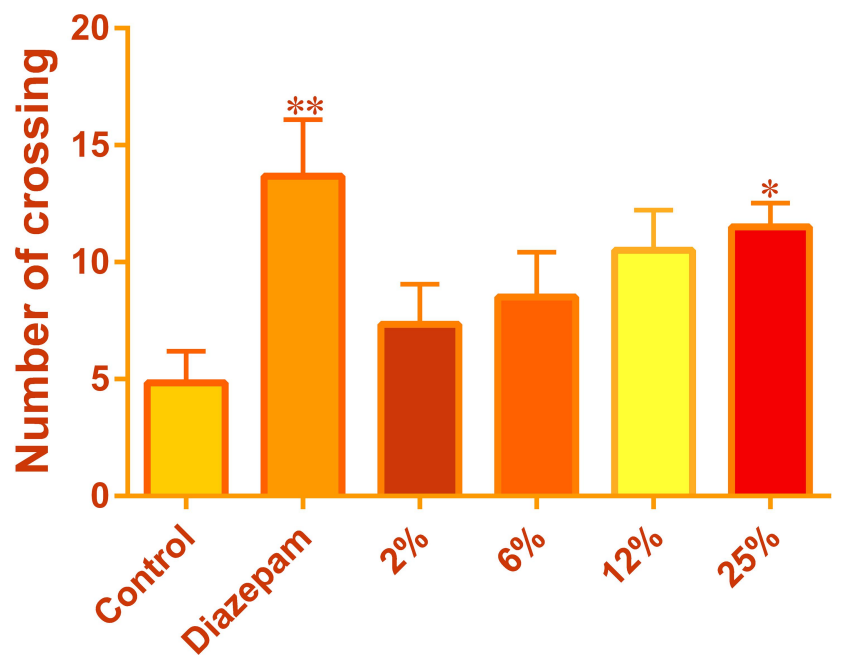

Figure 5 Effect of chehelghoza on a number of crossings.

Notes: Data are shown as mean \pm SEM. $* \mathrm{P}<0.05$, $* * P<0.01$ as compared with the control group.

\section{Effect of Chehelghoza on Brain Weight}

The wet brain weight was significantly increased in each $12 \%(1.39 \pm 0.05)$ and $25 \%(1.42 \pm 0.01)$ groups, as compared with the control group $(1.29 \pm 0.01)$. However, there was not a significant difference between control (1.29 $\pm 0.01)$ and each diazepam (1.33 \pm 0.02$), 2 \%(1.36 \pm 0.01)$ and $6 \%(1.36 \pm 0.02)$ groups (Figure 10 and Table 5).

\section{Effect of Chehelghoza on Body Weight}

The difference in the day 0 body weight between different groups was not significant. However, the day 28 body weight of each $2 \%(234.50 \pm 7.40), 6 \%$ (238.17 45.27$)$, 


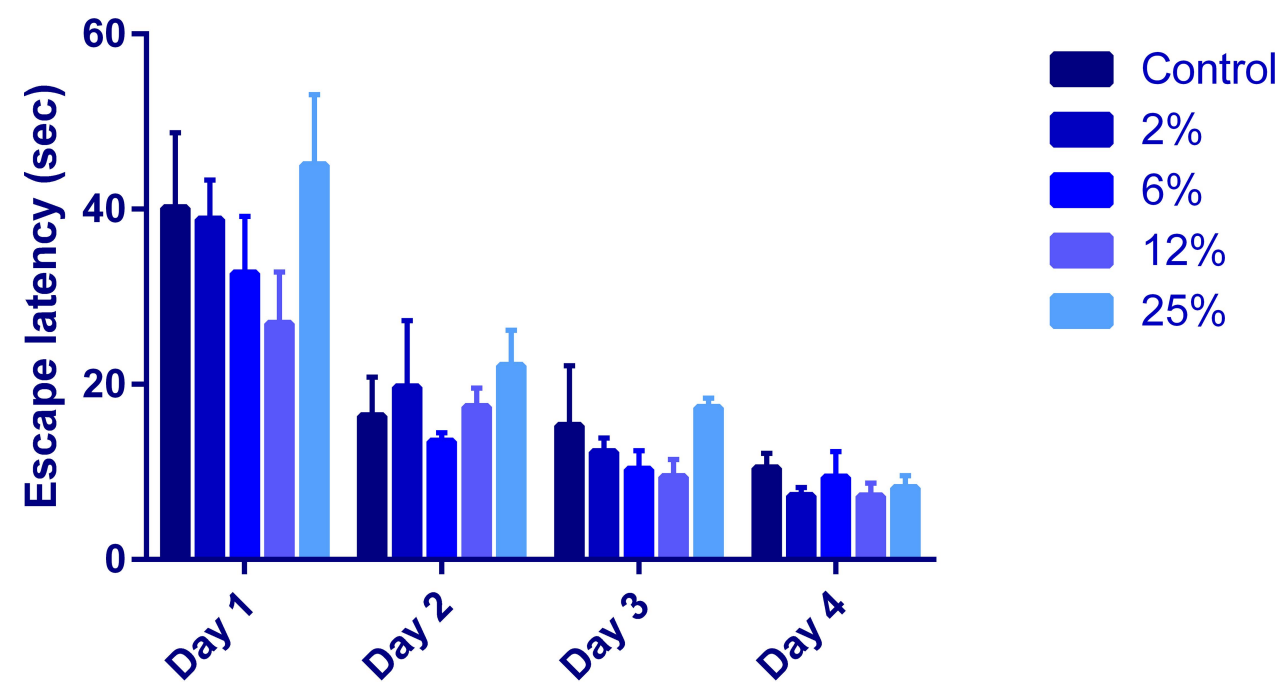

Figure 6 Effect of chehelghoza on escape latency. Notes: Data are shown as mean \pm SEM.

$12 \%(240.17 \pm 3.66)$ and $25 \%(242.17 \pm 5.19)$ groups was considerably decreased in comparison with the control group (269.17 \pm 4.50$)$. There was not a significant difference between day 28 body weight of control (269.17 $\pm 4.50)$ and diazepam (264.33 \pm 4.36$)$ group (Figure 11 and Table 5).

\section{Effect of Chehelghoza on Brain:Body Weight Ratio}

The difference in brain:body weight ratio between each $2 \% \quad(0.0058 \pm 0.00014), \quad 6 \% \quad(0.0057 \pm 0.00007), \quad 12 \%$ $(0.0058 \pm 0.00014)$ and $25 \% \quad(0.0059 \pm 0.00008)$ groups and the control group $(0.0047 \pm 0.00005)$ was significant. However, the difference between brain:body weight ratio of the diazepam $(0.0050 \pm 0.00002)$ and control $(0.0047$ \pm 0.00005 ) groups was not significant (Figure 12 and Table 5).

\section{Discussion}

The nature gifts various plants, fruits and nuts to human. ${ }^{7}$ Many researchers are focused on the use of natural compounds and medicinal plants. ${ }^{28}$ There are many plants and nuts such as Convulvulus pluricaulis, Evolvulus alsinoides, Canscora decussate, Juglans regia which are used for enhancement of learning and memory. ${ }^{18,29-31}$ In general, nuts have various beneficial constituents. Some of the nuts constituents may directly be related to brain function and physiology. For instance, walnut and pine nut have a large amount of unsaturated fatty acids, which excites the emotional experience-related brain areas. ${ }^{32}$

Table 3 Effect of Chehelghoza on Escape Latency and Time Spent in the Target Quadrant

\begin{tabular}{|c|c|c|c|c|c|}
\hline \multirow[t]{2}{*}{ Groups } & \multicolumn{4}{|c|}{ Escape Latency } & \multirow[t]{2}{*}{ Time Spent in Target Quadrant } \\
\hline & Day I & Day 2 & Day 3 & Day 4 & \\
\hline Control & $40.10 \pm 8.62$ & $16.36 \pm 4.48$ & $15.28 \pm 6.82$ & $10.43 \pm 1.67$ & $11.21 \pm 2.47$ \\
\hline $2 \%$ & $38.85 \pm 4.48$ & $19.68 \pm 7.58$ & $12.28 \pm 1.58$ & $7.26 \pm 0.98$ & $23.79 \pm 2.72$ \\
\hline $6 \%$ & $32.67 \pm 6.48$ & $13.49 \pm 0.97$ & $10.28 \pm 2.17$ & $9.38 \pm 2.95$ & $20.70 \pm 4.46$ \\
\hline $12 \%$ & $26.94 \pm 5.88$ & $17.40 \pm 2.16$ & $9.42 \pm 1.99$ & $7.22 \pm 1.50$ & $26.01 \pm 3.94 *$ \\
\hline \multirow[t]{2}{*}{$25 \%$} & $45.04 \pm 8.06$ & $22.13 \pm 4.02$ & $|7.3| \pm 1.09$ & $8.19 \pm 1.37$ & $26.85 \pm 4.55^{*}$ \\
\hline & $\begin{array}{l}\text { Two-Way } \\
F=1.068 \\
d f=4 \\
P=0.39\end{array}$ & & & & $\begin{array}{l}\text { One-Way ANOVA } \\
F=2.88 \\
d f=4 \\
P=0.04\end{array}$ \\
\hline
\end{tabular}

Note: Data are shown as mean \pm SEM. $* \mathrm{P}<0.05$ as compared with the control group.

Abbreviation: $d f$, degrees of freedom. 


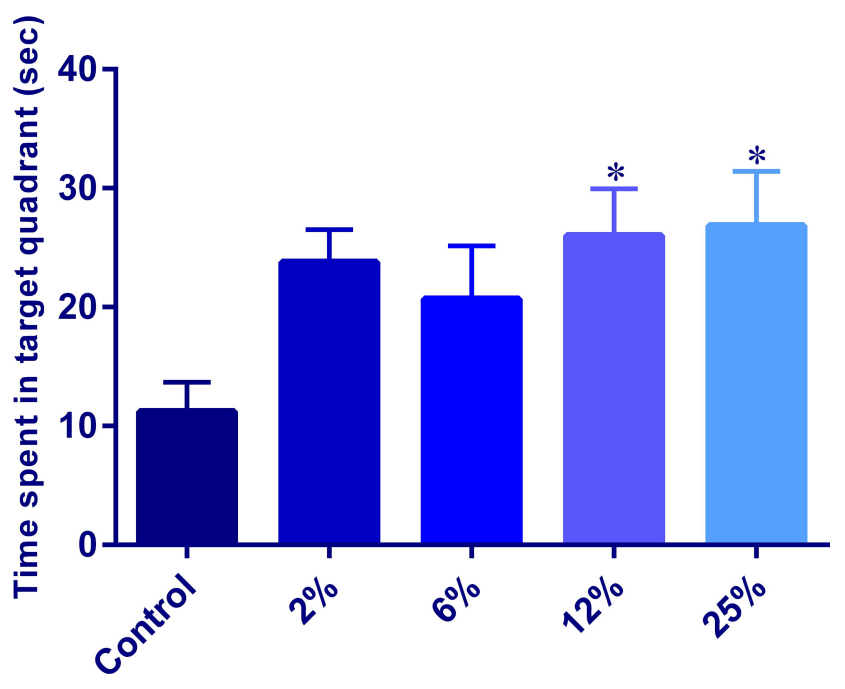

Figure 7 Effect of chehelghoza on time spent in the target quadrant. Notes: Data are shown as mean \pm SEM. $* P<0.05$ as compared with the control group.

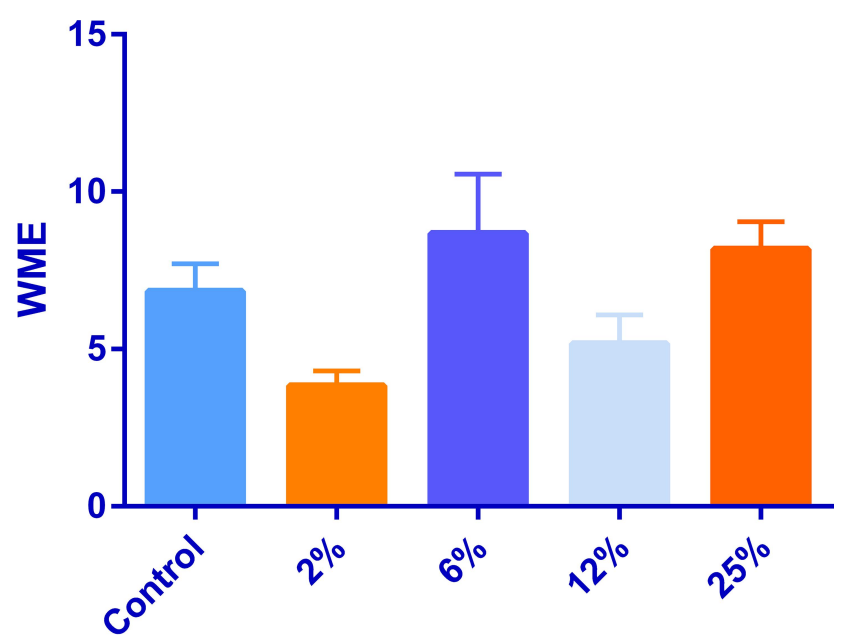

Figure 8 Effect of chehelghoza on WME.

Notes: Data are shown as mean \pm SEM.

Abbreviation: WME, working memory errors.

In this study, the effect of Afghan chehelghoza combined with diet on learning, memory, anxiety, brain weight and body weight in rats was evaluated behaviorally. The results have shown that chehelghoza can have an effect on rat's behavior as a dose-dependent manner. The administration of $25 \%$ chehelghoza combined with food could increase the $\% \mathrm{SA}$, an index of spatial working memory, whereas the $2 \%, 6 \%$ and $12 \%$ doses did not have a significant effect. Thus, chehelghoza can increase the spatial working memory only in high dose. The difference between the numbers of arm entries between different groups was not significant, so this excludes the falsepositive results.
Table 4 Effect of Chehelghoza on WME and RME

\begin{tabular}{|l|l|l|}
\hline \multirow{2}{*}{ Groups } & Parameters & RME \\
\cline { 2 - 3 } & WME & $5.50 \pm 0.43$ \\
Control & $6.83 \pm 0.87$ & $4.67 \pm 0.49$ \\
$6 \%$ & $3.83 \pm 0.48$ & $6.50 \pm 1.28$ \\
$12 \%$ & $8.67 \pm 1.89$ & $4.67 \pm 0.67$ \\
$25 \%$ & $5.17 \pm 0.91$ & $6.17 \pm 0.83$ \\
\hline & $8.17 \pm 0.87$ & Kruskal-Wallis \\
& One-Way ANOVA & \\
& $F=3.344$ & P $=0.288$ \\
\hline & df $=4$ & \\
& $P=0.025$ & \\
\hline
\end{tabular}

Note: Data are shown as Mean \pm SEM.

Abbreviations: $d f$, degrees of freedom; WME, working memory errors; RME, reference memory errors.

Also, the learning and reference memory was evaluated by MWM. Results have shown that neither doses of chehelghoza, which combined with food, could decrease the transfer latency as an index of learning. However, the $12 \%$ and $25 \%$ amounts of chehelghoza could significantly increase the time spent in target quadrant as an index of reference memory, whereas the $2 \%$ and $6 \%$ combinations did not have a significant effect.

Therefore, we can conclude that dietary chehelghoza can increase both short-term (working) memory and longterm (reference) memory in the rats.

As this is the first study conducted on the effect of chehelghoza on memory, we cannot compare the results of this study with any similar previous studies. However,

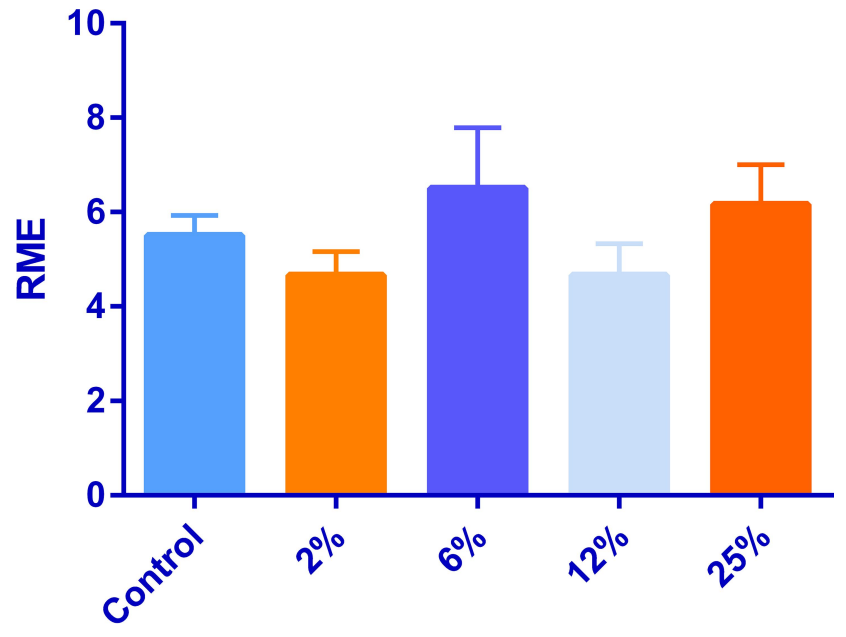

Figure 9 Effect of chehelghoza on RME.

Notes: Data are shown as mean \pm SEM.

Abbreviation: RME, reference memory errors. 


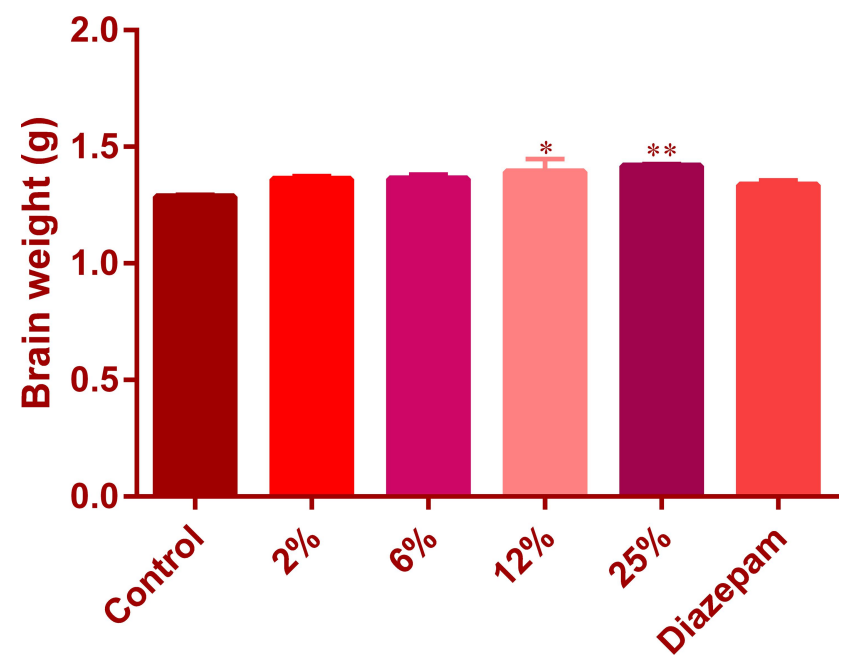

Figure 10 Effect of chehelghoza on brain weight.

Notes: Data are shown as mean \pm SEM. $* \mathrm{P}<0.05, * * \mathrm{P}<0.01$ as compared with the control group.

previous studies have been shown that different constituents of chehelghoza, such as polyunsaturated fatty acid (PUFA) and monounsaturated fatty acid (MUFA) have positive effects on memory-related brain areas and also on synaptic plasticity. ${ }^{33-36}$

Because the main constituents of chehelghoza pine nut are unsaturated fatty acids, ${ }^{8,9}$ the positive effect of chehelghoza on memory in this study may result from the presence of unsaturated fatty acids. Previous behavioral studies have shown that there is a relation between polyunsaturated fatty acid (PUFA) and cognition in mammals. ${ }^{33}$ Deficiency of PUFA in diet can affect ion channels activity, synaptic transmission and synaptic plasticity. In addition to multiple effects on inflammation, gene expression, apoptosis and cell-protecting activity, PUFA metabolites can improve signal transduction related to memory process, induction and maintenance of long-term potentiation (LTP). ${ }^{33,34}$

Long-chain PUFAs, including eicosapentaenoic acid and also other types, can increase the intracellular calcium concentration. $^{37}$ Studies showed that an increase of calcium directly modulates the biochemical processes of synaptic vesicle exocytosis and therefore neurotransmitters release. ${ }^{38}$ Levels of neurotransmitters is involved in building memory. ${ }^{29}$ The increase in calcium also causes synaptic changes, which are important for short-term and also long-term memory. ${ }^{39}$

Besides, the presence of PUFA in the diet can improve membrane fluidity and modulate synaptic transmission. For instance, long-term consumption of arachidonic acid increases the fluidity of hippocampal neuronal membranes. $^{33,40}$ There is a feedback control between long-chain PUFAs and numbers of insulin receptors in neurons, so an increase in membrane fluidity by longchain PUFAs increases the number of insulin receptors and affinity of the insulin to its receptors. ${ }^{37,40}$ PUFAs either directly or through an increase in insulin receptors can accelerate the glucose uptake. It is known that arachidonic acid excites the glucose uptake by cerebral cortex astrocytes. Glucose, in turn, can increase the release of acetylcholine and therefore the memory. ${ }^{40}$ Also, studies have shown that arachidonic and docosahexaenoic acid can increase the release of acetylcholine. ${ }^{37}$ Acetylcholine in the hippocampus controls the balance of encoding and retrieval especially in pyramidal cells of the CA1 region, thereby modulates synaptic plasticity. ${ }^{41}$

Table 5 Effect of Chehelghoza on Brain Weight, Body Weight and Brain:Body Weight Ratio

\begin{tabular}{|c|c|c|c|c|}
\hline \multirow[t]{2}{*}{ Groups } & \multicolumn{4}{|l|}{ Parameters } \\
\hline & Day 0 Body Weight & Day 28 Body Weight & Brain Weight & Brain:Body Weight Ratio \\
\hline Control & $205.83 \pm 1.58$ & $269.17 \pm 4.50$ & $1.29 \pm 0.01$ & $0.0047 \pm 0.00005$ \\
\hline $2 \%$ & $196.83 \pm 5.00$ & $234.50 \pm 7.40 * * * *$ & $1.36 \pm 0.01$ & $0.0058 \pm 0.00014 * *$ \\
\hline $6 \%$ & $195.50 \pm 3.72$ & $238.17 \pm 5.27 * * * *$ & $1.36 \pm 0.02$ & $0.0057 \pm 0.00007 * *$ \\
\hline $12 \%$ & $199.50 \pm 1.86$ & $240.17 \pm 3.66 * * * *$ & $1.39 \pm 0.05^{*}$ & $0.0058 \pm 0.00014^{* *}$ \\
\hline $25 \%$ & $195.67 \pm 3.94$ & $242.17 \pm 5.19 * * *$ & $1.42 \pm 0.01 * *$ & $0.0059 \pm 0.00008 * * *$ \\
\hline \multirow[t]{2}{*}{ Diazepam } & $206.17 \pm 1.87$ & $264.33 \pm 4.36$ & $1.33 \pm 0.02$ & $0.0050 \pm 0.00002$ \\
\hline & \multicolumn{2}{|l|}{$\begin{array}{l}\text { Two-way ANOVA } \\
F=7.08 \\
d f=5 \\
P=0.0002\end{array}$} & $\begin{array}{l}\text { One-Way ANOVA } \\
F=3.06 \\
d f=5 \\
P=0.0239\end{array}$ & $F=0.0001$ \\
\hline
\end{tabular}

Notes: Data are shown as mean \pm SEM. $* \mathrm{P}<0.05, * * \mathrm{P}<0.01, * * * \mathrm{P}<0.001$, $* * * * \mathrm{P}<0.000 \mathrm{I}$ as compared with the control group.

Abbreviation: $d f$, degrees of freedom. 


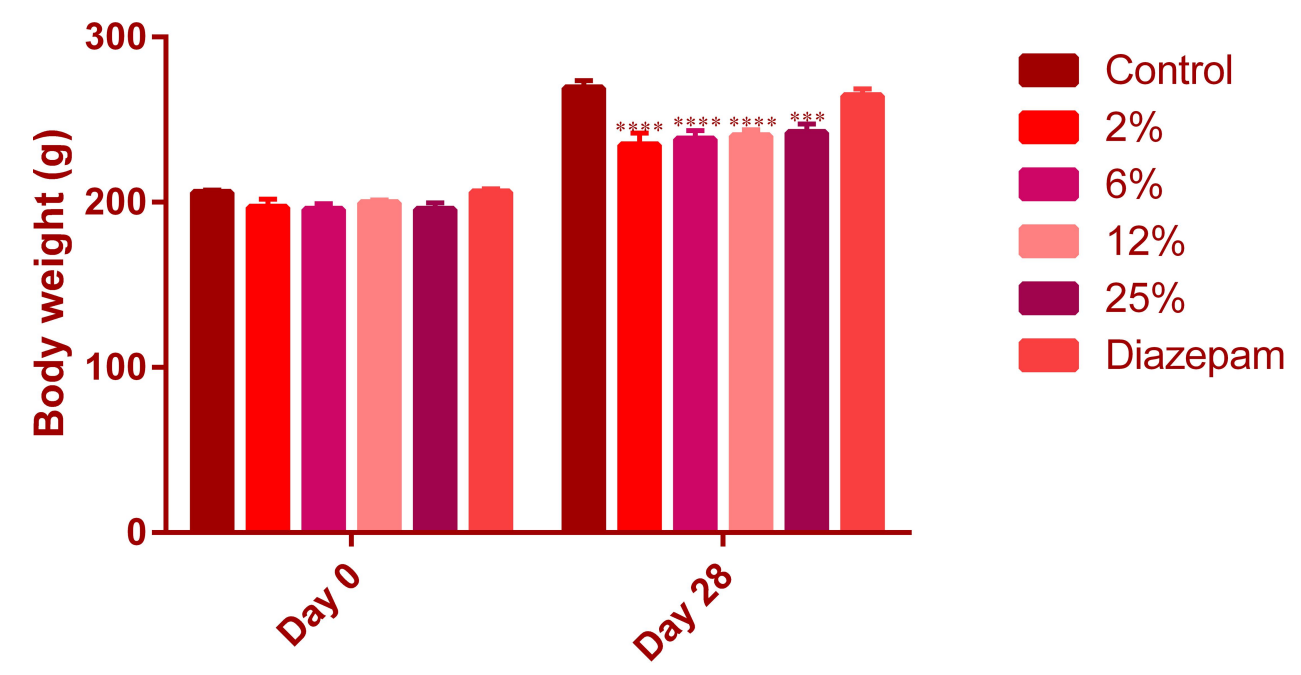

Figure I I Effect of chehelghoza on body weight.

Notes: Data are shown as mean \pm SEM. $* * * \mathrm{P}<0.001$, **** $\mathrm{P}<0.000 \mathrm{I}$ as compared with control group.

There is evidence that shows chehelghoza pine nut is rich in arginine. ${ }^{11}$ Arginine is a semi-essential amino-acid, which acts as a precursor of nitric oxide. ${ }^{42}$ Long-chain PUFAs also increase the synthesis of nitric oxide. ${ }^{37}$ Nitric oxide-cGMP pathway has an important role in the induction of LTP and memory process. ${ }^{42,43}$

In addition, chehelghoza pine nut is also rich in oleic acid. ${ }^{8,9}$ It is a monounsaturated fatty acid (MUFA), which is, considered as a neurotrophic factor in neurons. ${ }^{35,36}$ Oleic acid causes neuronal migration and synapse formation by an increase in presynaptic and postsynaptic protein gene expression. ${ }^{36}$ In general, it is believed that oleic acid can improve memory by an increase in LTP. ${ }^{44}$

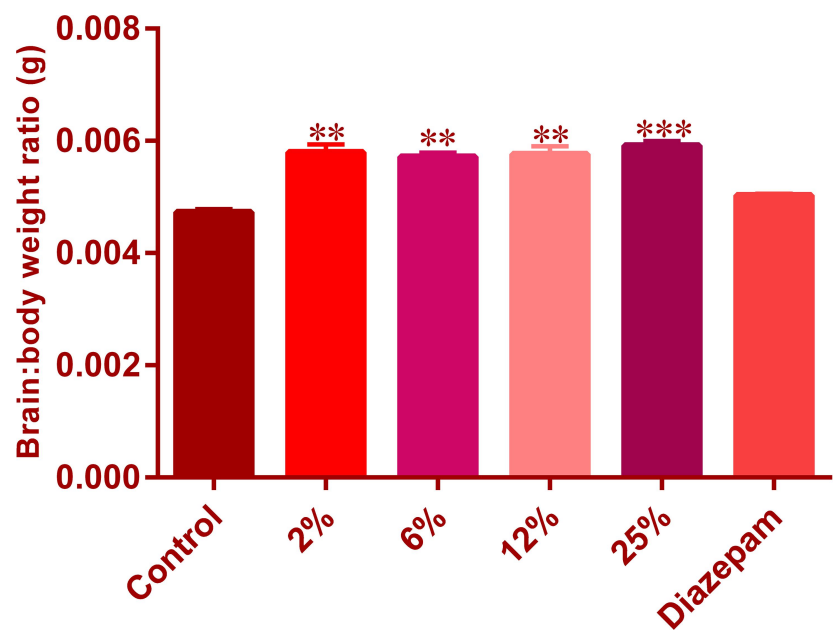

Figure 12 Effect of chehelghoza on brain:body weight ratio.

Notes: Data are shown as mean \pm SEM. $* * \mathrm{P}<0.0 \mathrm{I}$, $* * * \mathrm{P}<0.00 \mathrm{I}$ as compared with the control group.
By putting all the above matters together, one can conclude that chehelghoza pine nut because of containing most beneficial constituents such as PUFA, MUFA and arginine can improve memory through various mechanisms. Consumption of chehelghoza in the diet may cause an increase in calcium concentration, maintenance of membrane fluidity, increase in several insulin receptors and insulin affinity to its receptors, acceleration of glucose uptake by cell, increase in acetylcholine and nitric oxide neurotransmitters and therefore memory improvement.

Following other results, this study showed that high amounts of chehelghoza in the diet (12\% and 25\%) could increase the brain weight in rats, so the effect of $25 \%$ dietary chehelghoza was greater. Also, the brain:body weight ratio is increased in each 2, 6 and 12\% groups, and especially in the $25 \%$ group. These effects of chehelghoza on brain weight and brain:body weight ratio is also explained by the presence of PUFAs and MUFAs in this type of pine nut. As PUFAs and also oleic acid as neurotrophic factors can increase the gene expression of presynaptic and post-synaptic proteins, they are effective in axonal and dendritic and thus brain growth. ${ }^{35,40}$ The learning and memory capacity has been related to the absolute brain weight and its ratio with body. ${ }^{5,45}$ Increase in brain weight due to increase in neuron size, dendrite numbers and neuronal interconnections results in the improvement of learning and memory. ${ }^{5}$ So, the increase in brain weight resulting from chehelghoza consumption may be an indicator of brain growth and therefore memory enhancement.

In addition, results showed that neither amounts of dietary chehelghoza in this study could decrease the 
WME and RME. Because RAM is a reward-motivated model of spatial memory, ${ }^{23}$ probably, chehelghoza pine nut does not have any effect on this type of memory by these doses, which used in this study. Higher doses may affect.

Besides, the current study also investigated the effect of chehelghoza on the behavior of anxiety and stress and in comparison with diazepam. Results showed that $25 \%$ chehelghoza combined with food could increase the percentage of time spent in open arms, some entries into open arms and number of crossing, so its effect was little less than the anti-anxiety effect of diazepam. However, a low amount of chehelghoza did not have a significant effect on the rat's anxiety.

Similarly, a previous study has shown that oleic acid can exert sedative effects in infant rats. It is suggested that oleic acid can bind to benzodiazepine sites in GABA-A receptors, ${ }^{46}$ which modulates the opening of chloride channels. Most of the anti-anxiety compounds exert their anti-anxiety effect through acting on these receptors. ${ }^{46,47}$ Thus, it is probable that chehelghoza pine nut, because of containing oleic acid, can reduce anxiety and stress behavior by acting on GABA-A receptors.

The body weight of different groups was also evaluated. Results indicate that consumption of chehelghoza with food has effects on body weight even by the lowest amounts; so all amounts of dietary chehelghoza could decrease the body weight of rats after 28 days' treatment period. Similarly, previous studies have been shown that nuts generally because of containing PUFAs, MUFAs, high protein and dense energy may cause early satiety and reduction in body weight. ${ }^{4-50}$

\section{Conclusion}

One can conclude that high amounts of chehelghoza pine nut in combination with food can improve both short-term and long-term memory, reduce anxiety and stress behavior, and also increase in brain weight. The most effective dose percentage of chehelghoza pine nut combined with diet was $25 \%$. Based on the present finding, we can suggest further evaluation of the effect of chehelghoza pine nut on memory impairment, especially Alzheimer disease and age-related cognitive decline by behavioral studies and electrophysiological analysis methods.

\section{Abbreviations}

EPM, elevated plus maze; LTP, long-term potentiation; MWM, Morris water maze; MUFA, monounsaturated fatty acid; NIH, National Institute of Health; PUFA, polyunsaturated fatty acid; RAM, radial arm maze; RME, reference memory errors; WME, working memory errors; $\% \mathrm{SA}$, the percentage of spontaneous alternation.

\section{Ethics Approval}

This study was conducted on the ethical guidelines set by the eighth edition of the National Institute of Health (NIH) guide for the care and use of laboratory animals. The ethic research board of Khatam Al-Nabieen University approved the experimental protocol (Approval No. AF. KNU.REB.1397.16).

\section{Acknowledgments}

This study was supported by research and technology center of Khatam Al-Nabieen university (KNURTC), Kabul, Afghanistan. We thank all officials for their valuable support for providing the experiment and facilities for this study. We also thank Ms Ganjina Gawhar Yousofi, Ms Banafsha Zainal Bayat and Mr Khalil Ebrahimi for their collaboration in data acquisition. We especially thank the faculty of pharmacy and faculty of science of Kabul university.

\section{Author Contributions}

All authors contributed to data analysis, drafting or revising the article, have agreed on the journal to which the article will be submitted, gave final approval of the version to be published, and agree to be accountable for all aspects of the work.

\section{Disclosure}

The authors report no conflicts of interest in this work.

\section{References}

1. Bourre JM. Effects of nutrients (in food) on the structure and function of the nervous system: update on dietary requirements for brain. Part 1: micronutrients. J Nutr Health Aging. 2006;10:377.

2. Gómez-Pinilla F. Brain foods: the effects of nutrients on brain function. Nat Rev Neurosci. 2008;9(7):568-578. doi:10.1038/nrn2421

3. Gulyaeva NV. Molecular mechanisms of neuroplasticity: an expanding universe. Biochem (Mosc). 2017;82(3):237-242. doi:10.1134/ S0006297917030014

4. Amtul Z, Atta-Ur-Rahman A. Neural plasticity and memory: molecular mechanism. Rev Neurosci. 2015;26(3):253-268. doi:10.1515/ revneuro-2014-0075

5. Rensch B. Increase of learning capability with increase of brain-size. Am Nat. 1956;90(851):81-95. doi:10.1086/281911

6. Slutsky I, Abumaria N, Wu LJ, et al. Enhancement of learning and memory by elevating brain magnesium. Neuron. 2010;65(2):165-177. doi:10.1016/j.neuron.2009.12.026

7. Essa MM, Vijayan RK, Castellano-Gonzalez G, Memon MA, Braidy N, Guillemin GJ. Neuroprotective effect of natural products against Alzheimer's disease. Neurochem Res. 2012;37(9):1829-1842. doi:10. 1007/s11064-012-0799-9 
8. Sharma A, Sharma L, Goyal R. A review on himalayan pine species: ethnopharmacological, phytochemical and pharmacological aspects. Pharmacogn J. 2018;10(4):611-619. doi:10.5530/pj.2018.4.100

9. Thakur NS, Gupta A, Chauhan VK. Studies on quality characteristics of chilgoza nut and oil. Int J Farm Sci. 2015;5:78-82.

10. Thakur NS, Sharma S, Gupta R, Gupta A. Studies on drying and storage of chilgoza (Pinus gerardiana) nuts. J Food Sci Tech. 2014;51 (9):2092-2098. doi:10.1007/s13197-012-0692-1

11. Cai L, Xiao L, Liu C, Ying T. Functional properties and bioactivities of pine nut (Pinus gerardiana) protein isolates and its enzymatic hydrolysates. Food Bioprocess Tech. 2013;6(8):2109-2117. doi:10. 1007/s11947-012-0885-7

12. Rehman AU, Naz S, Zaman M, Saeed-ul-Hassan S, Iqbal J, Zaidi AA. A preliminary investigation of in vitro anti-thrombotic and antiplatelet activity of Pinus gerardiana. Biomed Res Ther. 2017;4 (1):1098-1109. doi:10.15419/bmrat.v4i1.145

13. Shalizi MN, Groninger JW, Khurram S, Ruffner CM, Burney OT. Data on ecological associations and stand structure of chilgoza pine (Pinus gerardiana Wall. ex D. Don) in Afghanistan. Data Brief. 2018;18:939-946. doi:10.1016/j.dib.2018.03.118

14. Safari S, Yousefi M, Khawari A, et al. Effect of Afghan Chehelghoza (Pinus gerardiana L.) on sperm parameters of male rats. J Food Nutr Disord. 2017;6:5.

15. Hoon LY, Choo C, Watawana MI, Jayawardena N, Waisundara VY. Evaluation of the total antioxidant capacity and antioxidant compounds of different solvent extracts of chilgoza pine nuts (Pinus gerardiana). J Func Food. 2015;18:1014-1021. doi:10.1016/j. jff.2014.07.009

16. Zulfqar F, Akhtar MF, Saleem A, Akhtar B, Sharif A, Saleem U. Chemical characterization, antioxidant evaluation, and antidiabetic potential of Pinus gerardiana (Pine nuts) extracts. J Food Biochem. 2020; 13199 .

17. Aydin E, Hritcu L, Dogan G, Hayta S, Bagci E. The effects of inhaled Pimpinella peregrina essential oil on scopolamine-induced memory impairment, anxiety, and depression in laboratory rats. Mol Neurobiol. 2016;53(9):6557-6567. doi:10.1007/s12035-016-9693-9

18. Harandi S, Golchin L, Ansari M, Moradi A, Shabani M, Sheibani V. Antiamnesic effects of walnuts consumption on scopolamine-induced memory impairments in rats. Basic Clin Neurosci. 2015;6:91.

19. Nahata A, Patil UK, Dixit VK. Anxiolytic activity of Evolvulus alsinoides and Convulvulus pluricaulis in rodents. Pharm Biol. 2009;47(5):444-451. doi:10.1080/13880200902822596

20. Sethiya NK, Nahata A, Dixit VK. Anxiolytic activity of Canscora decussata in albino rats. J Complement Integr Med. 2010;7(1). doi:10.2202/1553-3840.1263

21. Nunez J. Morris water maze experiment. J Vis Exp. 2008;24:e897.

22. Asadbegi M, Yaghmaei P, Salehi I, Komaki A, Ebrahim-Habibi A. Investigation of thymol effect on learning and memory impairment induced by intrahippocampal injection of amyloid beta peptide in high fat diet-fed rats. Metab Brain Dis. 2017;32(3):827-839. doi:10.1007/s11011-017-9960-0

23. Albayram O, Bilkei-Gorzo A, Zimmer A. Loss of CB1 receptors leads to differential age-related changes in reward-driven learning and memory. Front Aging Neurosci. 2012;4:34. doi:10.3389/ fnagi.2012.00034

24. Thorajak P, Pannangrong W, Welbat JU, Chaijaroonkhanarak W, Sripanidkulchai K, Sripanidkulchai B. Effects of aged garlic extract on cholinergic, glutamatergic and GABAergic systems with regard to cognitive impairment in A $\beta$-induced rats. Nutrients. 2017;9(7):686. doi:10.3390/nu9070686

25. Espina-Marchant P, Pinto-Hamuy T, Bustamante D, Morales P, Robles L, Herrera-Marschitz M. Spatial cognition and memory: a reversible lesion with lidocaine into the anteromedial/posterior parietal cortex (AM/PPC) affects differently working and long-term memory on two foraging tasks. Biol Res. 2006;39(4):601-609. doi:10.4067/S0716-97602006000500003
26. Papandreou MA, Dimakopoulou A, Linardaki ZI, et al. Effect of a polyphenol-rich wild blueberry extract on cognitive performance of mice, brain antioxidant markers and acetylcholinesterase activity. Behav Brain Res. 2009;198(2):352-358. doi:10.1016/j.bbr.2008.11.013

27. Iso H, Simoda S, Matsuyama T. Environmental change during postnatal development alters behaviour, cognitions and neurogenesis of mice. Behav Brain Res. 2007;179(1):90-98. doi:10.1016/j.bbr.2007. 01.025

28. Sadat H, Alami K, Mousavi SY. Effect of Afghan Senjed (Elaeagnus angustifolia L.) leaves aqueous alcoholic extract on blood glucose level of diabetic rats. Pharmacog J. 2020;12(6):1218-1222. doi:10. 5530/pj.2020.12.170

29. Nahata A, Patil UK, Dixit VK. Effect of Convulvulus pluricaulis choisy. on learning behaviour and memory enhancement activity in rodents. Nat Prod Res. 2008;22(16):1472-1482. doi:10.1080/ 14786410802214199

30. Nahata A, Patil UK, Dixit VK. Effect of Evolvulus alsinoides Linn. on learning behavior and memory enhancement activity in rodents. Phytother Res. 2010;24(4):486-493.

31. Sethiya NK, Nahata A, Dixit VK, Mishra SH. Cognition boosting effect of Canscora decussata (a South Indian Shankhpushpi). Eur J Integr Med. 2012;4(1):e113-121. doi:10.1016/j.eujim.2011.11.003

32. Grosso G, Estruch R. Nut consumption and age-related disease. Maturitas. 2016;84:11-16. doi:10.1016/j.maturitas.2015.10.014

33. Fukaya T, Gondaira T, Kashiyae Y, et al. Arachidonic acid preserves hippocampal neuron membrane fluidity in senescent rats. Neurobiol Aging. 2007;28(8):1179-1186. doi:10.1016/j.neurobiolaging.2006. 05.023

34. Tallima H, El Ridi R. Arachidonic acid: physiological roles and potential health benefits-a review. J Adv Res. 2018;11:33-41. doi:10.1016/j.jare.2017.11.004

35. Gorji N, Moeini R, Memariani Z. Almond, hazelnut and walnut, three nuts for neuroprotection in Alzheimer's disease: a neuropharmacological review of their bioactive constituents. Pharmacol Res. 2018;129:115-127. doi:10.1016/j.phrs.2017.12.003

36. Polo-Hernandez E, Tello V, Arroyo AA, et al. Oleic acid synthesized by stearoyl-CoA desaturase (SCD-1) in the lateral periventricular zone of the developing rat brain mediates neuronal growth, migration and the arrangement of prospective synapses. Brain Res. 2014;1570:13-25. doi:10.1016/j.brainres.2014.04.038

37. Das UN. Can memory be improved? A discussion on the role of ras, GABA, acetylcholine, NO, insulin, TNF- $\alpha$, and long-chain polyunsaturated fatty acids in memory formation and consolidation. Brain Dev. 2003;25(4):251-261. doi:10.1016/s0387-7604(02)00221-8

38. Citri A, Malenka RC. Synaptic plasticity: multiple forms, functions, and mechanisms. Neuropsychopharmacology. 2008;33:18-41.

39. Lamprecht R, LeDoux J. Structural plasticity and memory. Nat Rev Neurosci. 2004;5(1):45-54. doi:10.1038/nrn1301

40. Das UN. Long-chain polyunsaturated fatty acids in the growth and development of the brain and memory. Nutrition. 2003;19(1):62. doi:10.1016/S0899-9007(02)00852-3

41. Easton A, Douchamps V, Eacott M, Lever C. A specific role for septohippocampal acetylcholine in memory? Neuropsychologia. 2012;50:3156-3168.

42. Paul V, Ekambaram P. Involvement of nitric oxide in learning \& memory processes. Indian J Med Res. 2011;133:471.

43. Akar FY, Celikyurt IK, Ulak G, Mutlu O. Effects of $L$-Arginine on 7nitroindazole-induced reference and working memory performance of rats. Pharmacol. 2009;84(4):211-218. doi:10.1159/000235997

44. Kim E, Ko HJ, Jeon SJ, et al. The memory-enhancing effect of erucic acid on scopolamine-induced cognitive impairment in mice. Pharmacol Biochem Behav. 2016;142:85-90. doi:10.1016/j. pbb.2016.01.006

45. van der Woude E, Huigens ME, Smid HM. Differential effects of brain size on memory performance in parasitic wasps. Anim Behav. 2018;141:57-66. doi:10.1016/j.anbehav.2018.05.011 
46. Guillén-Ruiz G, Bernal-Morales B, Contreras CM, Cueto-Escobedo $\mathrm{J}$, Rodríguez-Landa JF. Oleic acid produces motor incoordination and hypoactivity in infant Wistar rats through $\mathrm{GABA}_{\mathrm{A}}$ receptors. $\mathrm{Am} \mathrm{J}$ Psychiatr Neurosci. 2016;4(2):18-25. doi:10.11648/j.ajpn.2016 0402.11

47. Akbari E, Alami K, Hossaini D, et al. Effect of Afghan Saffron (Crocus sativus L.) aqueous extract on withdrawal signs in morphine-dependent rats. Pharmacog J. 2020;12(6s):1727-1731. doi:10. 5530/pj.2020.12.234
48. Lutz M, Luna L. Nuts and body weight: an overview. J Nutr Health Sci. 2016;3:104.

49. Vadivel V, Kunyanga CN, Biesalski HK. Health benefits of nut consumption with special reference to body weight control. Nutrition. 2012;28(11-12):1089-1097. doi:10.1016/j.nut.2012.01.004

50. Tan SY, Dhillon J, Mattes RD. A review of the effects of nuts on appetite, food intake, metabolism, and body weight. Am J Clin Nutr. 2014;100(suppl_1):412S-422S. doi:10.3945/ajen.113.071456

\section{Publish your work in this journal}

Nutrition and Dietary Supplements is an international, peerreviewed, open access journal focusing on research into nutritional requirements in health and disease, impact on metabolism and the identification and optimal use of dietary strategies and supplements necessary for normal growth and development. The journal welcomes submitted papers covering original research, basic science, clinical \& epidemiological studies, reviews and evaluations, guidelines, expert opinion and commentary, case reports and extended reports. The manuscript management system is completely online and includes a very quick and fair peer-review system, which is all easy to use. Visit http://www.dovepress.com/testimonials.php to read real quotes from published authors. 